\title{
NOTE
}

\section{Effect of Hurricane Hugo on the primary framework of a reef along the south shore of St. John, US Virgin Islands}

\author{
Peter J. Edmunds*, Jon D. Witman \\ Northeastern University, Marine Science Center, East Point, Nahant, Massachusetts 01908, USA
}

\begin{abstract}
Hurricane Hugo (1989) severely damaged the framebuilding coral Montastrea annularis on the shallow reefs in Greater Lameshur Bay, St. John. Before the storm these reefs were dominated by $M$. annularis and a permanent study area was established at $10 \mathrm{~m}$ depth to monitor changes in abundance of this species. The storm destroyed, on average, $>33 \%$ of the live cover of $M$. annularis in the study area. Post-hurricane reefs contained numerous detached colonies in piles or packed into cavities within the reef framework, large areas of vacant hard substratum and extensive growths of the red algae Liagora spp. Video transects $\left(80 \mathrm{~m}^{2}\right)$ at the same depth and on either side of the study area showed that this damage was patchy. Although these reefs may remain dominated by $M$. annularis it is possible that the scleractinian fauna will change as a result of colonization by other coral species and delayed mortality of detached $M$. annularis colonies.
\end{abstract}

Hurricanes regularly impact Caribbean regions (e.g. Glynn et al. 1964, Stoddart 1985) causing severe damage to terrestrial and marine communities. Sustained wind speeds can exceed $120 \mathrm{~km} \mathrm{~h}^{-1}$ and may gust to more than $300 \mathrm{~km} \mathrm{~h}^{-1}$, while hurricane waves have been recorded as high as $23.6 \mathrm{~m}$ (Stoddart 1985). The most comprehensive description of hurricane effects on coral reefs is for Discovery Bay, Jamaica, where baseline data were available for more than 2 decades before Hurricane Allen hit the island in 1980 (Woodley et al. 1981).

Hurricane Allen severely affected both sessile and mobile fauna on Jamaican reefs, although the effect was patchy and showed variation among coral species. The planar area of branching corals such as Acropora cervicornis was reduced by up to $99 \%$ but massive colonies such as Montastrea annularis lost only $9 \%$ of their area at $6 \mathrm{~m}$ depth (Woodley et al. 1981). More

\footnotetext{
- Present address and reprint requests: University of Southern California, Catalina Marine Science Center, PO Box 398, Avalon, California 90704, USA
}

extensive damage to $M$. annularis occurred at $10 \mathrm{~m}$ depth, where up to $65 \%$ of the massive head corals (brain corals and $M$. annularis pooled) were toppled. Catastrophic damage to delicate corals and the survival of robust massive colonies is common during major storms (Rogers et al. 1982, Stoddart 1985, Kjerve et al. 1986) and has important implications because massive corals build the framework of coral reefs (Sheppard 1982).

On 18 September 1989, Hurricane Hugo passed ca $56 \mathrm{~km}$ to the south of St. John, US Virgin Islands, with sustained winds of $225 \mathrm{~km} \mathrm{~h}^{-1}$ and gusts of $320 \mathrm{~km} \mathrm{~h}^{-1}$ (Climate Analysis Center 1989). Greater Lameshur Bay (GLB) has a southerly aspect and an axis perpendicular to the storm and, therefore, was exposed to the full force of the hurricane waves. In 1987 permanent study sites had been established in GLB to monitor changes in abundance of the primary framework coral Montastrea annularis which dominated the shallow reefs (10 m depth) of GLB (Edmunds et al. 1990) with columnar-lobate colonies. These areas provided the opportunity to determine the effect of Hurricane Hugo on the reef framework and this note describes the results of our quantitative analyses.

Methods. The study site is at $10 \mathrm{~m}$ depth off the tip of Yawzi Point in GLB and consists of adjacent quadrats ( $\mathrm{n}=10$, each $0.75 \mathrm{~m}^{2}$ ) along each of three $10 \mathrm{~m}$ long transect lines (total of 30 quadrats) which are parallel to one another and are permanently marked. Quadrats were photographed in April 1989 and 6 wk after Hurricane Hugo (Nikonos V, $28 \mathrm{~mm}$ lens). Projected color slides were overlaid with a grid of 200 randomly spaced dots to determine percent cover of Montastrea annularis, the red algae Liagora spp. (mostly L. mucosa) and free space (hard substrata: rock and coral rock) from the proportion of dots on each substratum. $M$. annularis was the only coral quantified in these 
areas because it formed a virtual monospecific stand and the photoquadrats required to measure colonies (> $1 \mathrm{~m}$ diameter) of this species did not have sufficient resolution to detect other, less abundant, scleractinians (Edmunds et al. 1990). Sand substratum was not quantified because coral planulae larvae will only settle on solid substrata (Fadlallah 1983).

Many of the columnar-lobate colonies of Montastrea annularis were broken into individual lobes by Hurricane Hugo but this type of damage was not accurately quantified with surface area determinations. Therefore, in each slide we counted the $M$. annularis lobes that were detached from the substratum and expressed them as a percent of the total lobes present

To increase the area of our post-hurricane surveys, four $20 \mathrm{~m}$ long band transects were filmed at the same depth as the permanent quadrats using a hand-held high resolution Sony V99 ${ }^{\mathrm{TM}}$ video camera aimed vertically downward. Band transects were perpendicular to the ends of the 2 outer, permanently marked transect lines. Sequential, non-overlapping fields of view (each $1.0 \mathrm{~m}^{2}$ ) were freeze-framed on a color monitor and substrata areas determined using a grid of 200 randomly spaced dots as described above. To determine the size of the living tissue remaining on fragments, detached lobes were selected at random from the video and the outlines of their living tissue were traced onto plastic sheets. The planar area of the live tissue was then measured by digitizing the individual outlines.

All percent cover data were arcsine-transformed before analysis (Sokal \& Rohlf 1981) and were compared between times with a Student $t$-test.

Results. Hurricane Hugo resulted in significant changes to the primary framework coral in GLB. Some of the colonies used as reference points for the study area were completely destroyed and we were unable to relocate 12 of the quadrats. Thus, the estimate of reef destruction is conservative because it does not include these 12 quadrats with extensive coral damage.

There were significant changes in substratum composition as a result of Hurricane Hugo (Fig. 1). Mean percent cover of Montastred annularis decreased by $34 \%(42 \%$ to $28 \%, t=2.048, \mathrm{df}=46, \mathrm{p}<0.05)$, detached lobes of $M$. annularis increased by 13 -fold ( $2 \%$ to $25 \% ; t=3.271, \mathrm{df}=46, \mathrm{p}<0.01$ ) and free space increased by $82 \%(15 \%$ to $27 \% ; t=3.311, \mathrm{df}=46$, $p<0.01)$. The cover of Liagora spp. increased $(t=5.722$, $\mathrm{df}=46, \mathrm{p}<0.001$ ) from $0 \%$ to $11 \%$, and inspection of the color slides showed that most of the Liagora spp. were not growing on living $M$. annularis but on additional free space created by the storm. This suggests that Hurricane Hugo resulted in a $153 \%$ increase in free space as determined from the sum of the space occupied by Liagora spp. and the free space (Fig. 1).

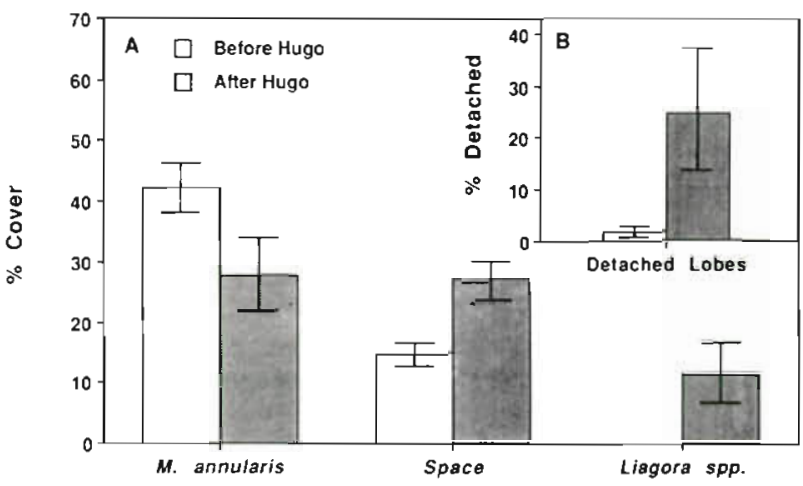

Fig 1. Comparison of pre-and post-hurricane reef in the permanent study area. (A) Percent cover of substrata, and (B) percent of the Montastrea annularis lobes that were detached. Mean and SE shown for arcsine-transformed data (Sokal \& Rohlf 1981)

The video transects showed that the cover of each substratum, and the percentage of broken lobes varied more than an order of magnitude across a horizontal distance of $50 \mathrm{~m}$ (Fig. 2). Furthermore, there was an inverse relationship between the cover of Montastrea annularis and detached lobes along Transect A- $\mathrm{A}^{\prime}(\mathrm{r}=$ $-0.404, \mathrm{df}=34, \mathrm{p}<0.02)$ although this was not significant along $B-B^{\prime}(r=0.245, d f=34, p=0.05)$ (Fig. 2 ). After the hurricane the reef adjacent to the permanent study area consisted of 5 to $7 \mathrm{~m}$ wide patches of living M. annularis surrounded by large areas of free space and broken lobes, each covered with $21 \pm 2 \mathrm{~cm}^{2}$ (mean $\pm \mathrm{SE}, \mathrm{n}=100$ ) of living tissue.

Discussion. Hurricane Hugo severely damaged colonies of Montastrea annularis which dominated the shallow reefs of Greater Lameshur Bay before the storm. Other studies of the impact of hurricanes on marine communities have also described the loss of scleractinians, particularly delicate branching species (Highsmith et al. 1980, Woodley et al. 1981. Rogers et al. 1982) and a few record 'total' reef destruction (e.g. Stoddart 1974), although these may result from more qualitative approaches. In contrast, the present study quantifies hurricane effects on the massive coral $M$. annularis which is the primary framework coral on Caribbean reefs (Goreau 1959. Glynn 1973, Liddell \& Ohlhorst 1987) and which, therefore, has a crucial role in reef growth. Our findings are corroborated by the close agreement with the results of Rogers et al. (1991 - this issue), who quantified the effects of Hurricane Hugo on a reef adjacent to our study area.

Large numbers of columnar-lobate colonies of Montastrea annularis were split by hurricane waves (Fig. 1), resulting in fragmentation and a major decrease in coverage of $M$. annularis. Some broken lobes were oriented so that it was impossible to 
Transect A-A'

Substrate Cover
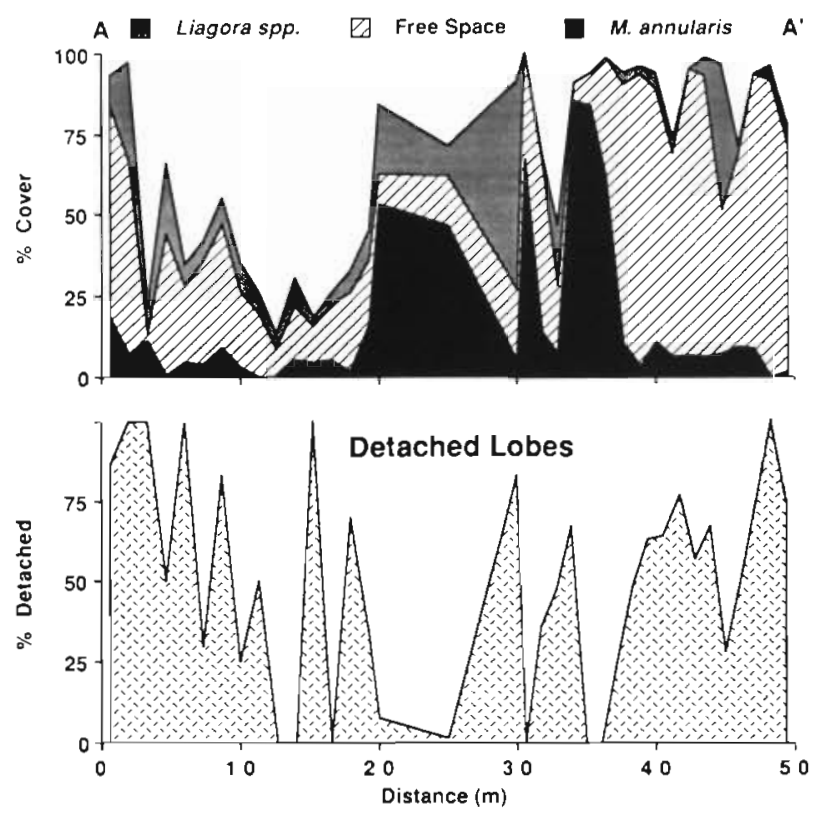

Transect B-B'

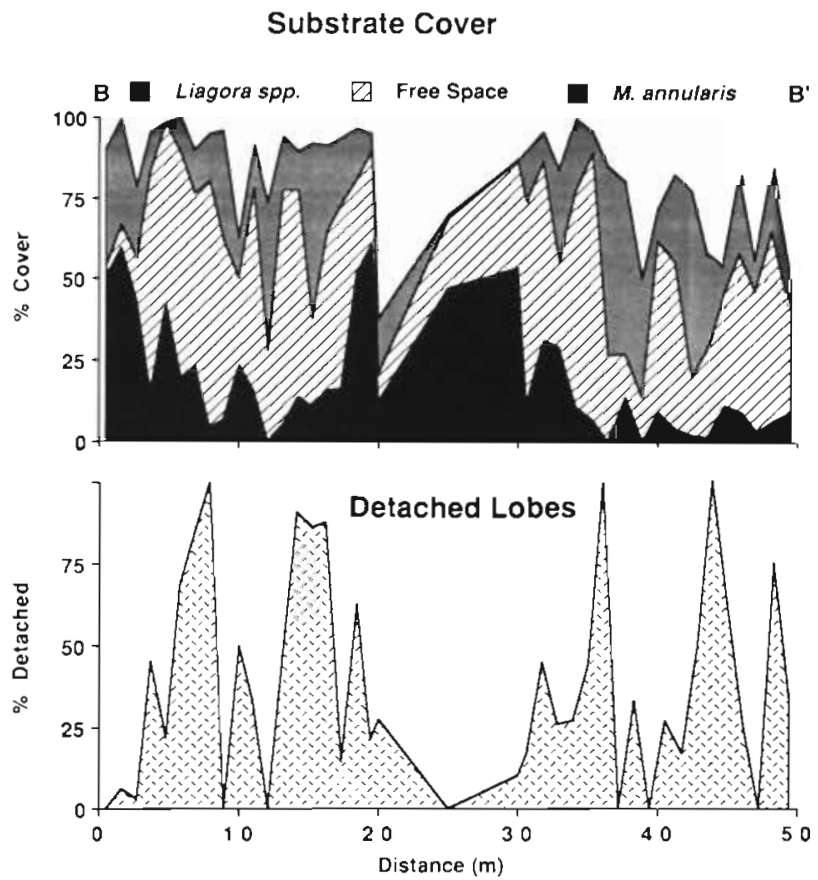

Fig. 2. Substratum cover and percentage of detached Montastrea annularis lobes in the video surveys. Four $20 \mathrm{~m}$ long transects running perpendicular from the ends of the outer 2 permanently marked transects, which were $10 \mathrm{~m}$ apart, were filmed. The pair of video transects that were at the same end of the permanent study area and which ran along the same axis are plotted together to provide a reef profile consisting of $40 \mathrm{~m}$ of video transect plus the $10 \mathrm{~m}$ in between $\left(\mathrm{A}^{-} \mathrm{A}^{\prime}\right.$ and $\mathrm{B}-\mathrm{B}^{\prime}$; data at $20 \mathrm{~m}, 25 \mathrm{~m}$ and $30 \mathrm{~m}$ are from the photoquadrats intersected by the video transect and the permanent study area)

use photographs to determine whether they were detached from the reef and, therefore, our data may underestimate the actual extent of fragmentation. Most detached colonies were transported across the reef and accumulated in hollows and on top of other colonies leading to a reduction in topographic complexity which may adversely effect fish populations (Luckhurst \& Luckhurst 1978) and solitary cryptofauna (Moran \& Reaka-Kudla 1991), in addition to destroying reef corals.

Even though the areas recorded on video were not surveyed before the hurricane, the appearance of freshly broken coral fragments, toppled heads, free space and Liagora spp. $6 \mathrm{wk}$ after the storm provide evidence that the damage was a result of Hurricane Hugo. Although detached but still living colonies of Montastrea annularis were scattered all over the reef, most of the damage was patchy (Fig. 2) and this may have accounted for the inverse relationship of numbers of lobes and percent cover of $M$. annularis in the video transect $A-A^{\prime}$ (Fig. 2). The distribution of coral cover before Hurricane Hugo may also have influenced the pattern of damage observed in the video transects but, nevertheless, the interpretation of patchy damage agrees with previous descriptions of similar hurricane damage (Woodley et al. 1981).

Patchy damage was partly the result of a 'domino effect' of reef destruction, whereby coral fragments crash through stands of coral colonies, thereby resulting in the propagation of destruction. This occurred on Jamaican reefs during Hurricane Allen among massive corals (Woodley et al. 1981) and colonies of Acropora cervicornis (Tunnicliffe 1981) and similar processes damaged $M$. annularis during Hurricane Hugo. In at least 12 cases the trajectories of detached colonies could be traced by their trail of destruction before coming to rest. Some of the permanent quadrats showed this effect in the immigration of colonies of $M$. annularis, many of which were pitted from direct hits by water-borne projectiles.

Fragmentation of columnar-lobate colonies of Montastrea annularis exposed the sides of the individual cone-shaped lobes thereby contributing substantially to the $153 \%$ increase in vacant substrata recorded in the present study. Much of this space was occupied by extensive growths of the algae Liagora spp. which covered $11 \%$ of the reef after Hurricane Hugo and are typically rapid colonizers of patches created by hurricanes (Woodley et al. 1981, Rogers et al. 1982). 
Subsequent recruitment and mortality may drastically alter the scleractinian fauna of the reefs in GLB. We predict 3 scenarios for these changes: (1) recolonization by opportunistic coral species such as Agaricia agaricites (Bak \& Engel 1979), which was abundant before the hurricane (Edmunds et al. 1990) and was 1 of the 3 coral species recruiting (together with Porites astreoides and Favia fragum) between 1985 and 1989 into 32 permanent quadrats of $0.25 \mathrm{~m}^{2}$ at 4 and $12 \mathrm{~m}$ depth on the eastern side of GLB (J. D. Witman unpubl.); (2) alteration in community structures which may be exacerbated by the death of the detached lobes of Montastrea annularis since many may be too small (21 $\mathrm{cm}^{2}$ of live tissue) to survive (sensu Highsmith 1982); (3) regrowth of broken lobes leading to the reestablishment of a reef dominated by $M$. annularis Most surviving fragments of $M$. annularis are too small to be sexually mature (Szmant-Froelich 1985) and therefore could not supply larvae to help repopulate the reef.

Acknowledgements. This work was partially funded by the National Park Service under its Coral Reef Assessment Program (contract \# CA 5000-8-8013) and the School for Field Studies. We thank C. S. Rogers of the Virgin Islands National Park Service for assistance and field facilities and the staff of the Virgin Islands Ecological Research Station for making this research possible. We thank K. Watkins and $J$ Bruno for analyzing the images at the Marine Science Center (MSC), Nahant, and K. Sebens and J. Ayers for valuable comments on earlier drafts of this paper. This is MSC contribution number 187

\section{LITERATURE CITED}

Bak, R. P. M., Engel, M. S. (1979). Distribution, abundance and survival of juvenile hermatypic corals (Scleractinia) and the importance of life history strategies in the parent coral community. Mar. Biol. 70: 101-104

Climate Analysis Center (1989). Weekly Climate Bulletin No. 89/38 Dept of Commerce, National Oceanic and Atmospheric Administration, Washington, D.C

Edmunds, P. J., Roberts, D. A., Singer, R. (1990). Reefs on the northeastern Caribbean I. Scleractinian populations. Bull. mar. Sci. 46: 780-789

Fadlallah, Y H. (1983). Sexual reproduction, development and larval biology in scleractinian corals. A review. Coral Reefs 2: $129-150$

Glynn P. W. (1973). Aspects of the ecology of coral reefs in the western Atlantic region. In: Jones, O A., Endean, R. (eds.)

This note was submitted to the editor
Biology and geology of coral reefs, Vol. 2. Academic Press, London, p. 271-324

Glynn, P. W., Almodovar, L. R., Gonzalez, J. G. (1964). Effects of Hurncane Edith on marine life in La Paguera, Puerto Rico. Caribb. J. Sci. 4: 335-345

Goreau, T. F. (1959). The ecology of Jamaican coral reefs I. Species composition and zonation. Ecology 40:67-90

Highsmith, R. C. (1982) Reproduction by fragmentation in corals. Mar. Ecol. Prog. Ser. 7: 207-226

Highsmith, R. C., Riggs, A. C., D'Antonio, C. M. (1980). Survival of hurricane generated fragments and a disturbance model of reef calcification/growth rates. Oecologia 46: $322-329$

Kjerfve, B., Magill, K. E., Porter, J. W., Woodley, J. D. (1986). Hindcasting of hurricane characteristics and observed storm damage on a fringing reef, Jamaica, West Indies. J. mar. Res. 44: 119-148

Liddell, D. W., Ohlhorst, S. L. (1987). Patterns of reef community structure, north Jamaica. Bull. mar. Sci. 40: 311-329

Luckhurst, B. E., Luckhurst, K. (1978). Analysis of the influence of substrate variables on coral reef fish communities. Mar. Biol. 49: 317-323

Moran, D. P., Reaka-Kudla, M. L. (1991). Effects of disturbance: distribution and enhancement of coral reef cryptofaunal populations by hurricanes. Coral Reefs 9: 215-224

Rogers, C. S., Teytaud, R. (1988). Marine and terrestrial ecosystems of the Virgin Islands National Park and Biosphere Reserve. Biosphere Reserve Report No. 29, U.S. Dept of the Interior and Virgin Islands Resource Management Cooperative, St. Thomas, USVI, $112 \mathrm{pp}$.

Rogers, C. S., McClain, L. N., Tobias, C. R. (1991). Effects of Hurricane Hugo (1989) on a coral reef in St. John, USVI. Mar. Ecol. Prog. Ser. 78: 189-199

Rogers. C. S., Suchanek, T. H., Pecora, F. A. (1982). Effects of Hurricanes David and Frederic (1979) on shallow Acropora palmata reef communities: St. Croix, U.S. Virgin Islands. Bull. mar. Sci. 32: 532-548

Sheppard, C. R. C. (1982). Coral populations on reef slopes and their major controls. Mar. Ecol. Prog. Ser. 7: 83-115

Sokal, R. R., Rohlf, F. J. (1981). Biometry. W. H. Freeman \& Co., New York

Stoddart, D. R. (1974). Post hurricane changes on the British Honduras reefs: re-survey of 1972. Proc. 2nd. int. Coral Reef Symp., Brisbane 2: 473-483

Stoddart, D. R. (1985). Hurricane effects on coral reefs. Proc. 5th. int. Coral Reef Symp., Tahiti 3:349-350

Szmant-Froelich, A. (1985). The effect of colony size on the reproductive ability of the Caribbean coral Montastrea annularis (Ellis \& Solander). Proc. 5th. int. Coral Reef Symp. Tahiti 4: 295-300

Tunnicliffe. V. (1981). Breakage and propagation of the stony coral Acropora cervicornis. Proc natn. Acad. Sci. 78: $2427-2431$

Woodley, J. D., and 19 others (1981). Hurricane Allen's impact on Jamaican coral reefs. Science 214: 749-755

Manuscript first received: July 1, 1991

Revised version accepted: November 4, 1991 